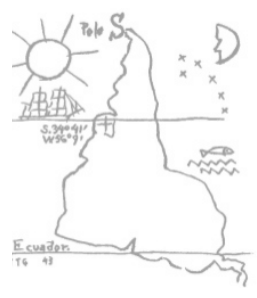

\title{
ALTERNAUTAS
}

Vol.5 - Issue 2 [December 2018]

Fernando Tormos

\section{The Politics of Survival in Puerto Rico: The Balance of Forces in the Wake of Hurricane María}

$\overline{\text { Alternautas is a peer reviewed academic journal that publishes content related to }}$ Latin American Critical Development Thinking.

It intends to serve as a platform for testing, circulating, and debating new ideas and reflections on these topics, expanding beyond the geographical, cultural and linguistic boundaries of Latin America - Abya Yala. We hope to contribute to connecting ideas, and to provide a space for intellectual exchange and discussion for a nascent academic community of scholars, devoted to counterbalancing mainstream understandings of development.

How to cite:

Tormos Fernando. (2018), The Politics of Survival in Puerto Rico: The Balance of

Forces in the Wake of Hurricane María. Alternautas, 5(2), 79-94. URL :

http://www.alternautas.net/blog/2018/11/16/the-politics-of-survival-in-puerto-ri the-balance-of-forces-in-the-wake-of-hurricane-mara

Editor : Alternautas

http://www.alternautas.net

London, UK.

ISSN - 2057-4924 


\section{The Politics of Survival in Puerto Rico: The Balance of Forces in the Wake of Hurricane María ${ }^{2}$}

Puerto Rico's left-wing forces have long tried to unify, a goal that has proven difficult to reach and even harder to sustain. ${ }^{3}$ At its strongest, the Left has faced intense repression from both the United States and the island's colonial government. Yet, activists and left-wing intellectuals agree that deeper differences account for the collective inability to build unity. ${ }^{4}$ Historically, left-wing forces in Puerto Rico have

\footnotetext{
1 FERNANDO TORMOS-APONTE is a postdoctoral fellow with the Scholars Strategy Network based at the University of Missouri in St. Louis and a research fellow of the Southern Methodist University Latino Center for Leadership Development. His research focuses on how social movements overcome internal divisions and gain political influence.

${ }^{2}$ This article was originally published in http://www.alternautas.net/blog/2018/11/16/the-politicsof-survival-in-puerto-rico-the-balance-of-forces-in-the-wake-of-hurricane-mara on November $16^{\text {th }}, 2018$.

3 This article adopts an expansive notion of the Left/Right ideological spectrum. Rather than limiting the definition of "Left" to social movement organizations engaged in activism over economic matters, this article refers to the Left as an ample network of organizations that have a history of collaborating on a range of issues, including anti-militarism, independence, labor rights, privatization of public services and institutions, civil rights, health, gender, and sexuality. The tensions among these groups do not preclude their collaboration and tendency to join in opposition to conservative policies. In the context of Puerto Rico, as in other contexts, people tend to use the concept of the Left in remarkably similar ways (see Bakker et al 2014 and Cochrane 2015).

${ }^{4}$ See, for example, Noel Colón Martínez, cited in José “Ché” Paralitici's $(2017,220)$ Historia de la Lucha de la Independencia de Puerto Rico, and Carlos Pabón's essay “Después de las Elecciones: ¿Alianzas para qué? ¿Entre quiénes? In Polémicas: Política, Intelectuales, violencia.
}

** 
split over the national question. Pro-independence groups, arguably the largest sector, have prioritized decolonization while socialists, feminists, and environmentalists have proposed a broader anti-oppressive praxis centered on social and economic issues. Other groups, such as the Movimiento Socialista de Trabajadores, do not see these struggles as mutually exclusive, calling for the formation of a socialist republic in Puerto Rico. ${ }^{5}$

Today a new wave of Leftist organizing is emerging, one free from traditional Marxist or nationalist dogmas. This new Puerto Rican Left is organizing for economic justice and against colonialism while putting a greater emphasis on gender, sexuality, and race. It aims to foster young leadership, articulate new solidarities, and revive the practice of community organizing. It is learning from the errors of the past while picking up the sediments of previous struggles. ${ }^{6}$ Yet, if the Left wants to remain relevant, it must collaborate with the youth, student, community, feminist, farmer, and environmental justice groups that are bringing new energy to the island. This essay contextualizes the Puerto Rican Left in relation to the island's political economy, identifies the forces in the Puerto Rican Left, reviews their differences and recent history, and presents a brief analysis of their political influence in Puerto Rican and US politics.

\section{The Struggle Against Neoliberalism}

In 2010, Luis Fortuño's conservative administration attacked the Puerto Rican public sector. The economy was in crisis, and Fortuño and his advisory council were

\footnotetext{
5 See the following link for more information on the aims of the Movimiento Socialista de Trabajadores: http://www.bandera.org/que-es-y-porque-lucha-el-mst/

6 The reference to sediments from previous struggles is drawn from Colin Barker's 1995 article “'The Muck of Ages': Reflections on Proletarian Self-emancipation," in which Barker argued: "Movements do rise, peak and fall back, moving through internal crises on the way. But as they decline, and 'normality' reasserts itself, they leave 'sediments' behind." Barker's article is available at: <https://goo.gl/LkU4 $4 \mathrm{~N}$ >
} 
confident that the problem had a familiar solution — economic austerity. ${ }^{7}$ His government went after unions, social policies, and most violently, higher education. In response, a popular front came together in order to defeat a common enemy: Fortuño and the private interests he so faithfully represented. The island had seldom been so polarized, with neoliberal forces preparing to strike a fatal blow and opposition groups looking for ways to resist. The Puerto Rican Left aimed to build an emancipatory struggle connected to the global wave of resistance that included Occupiers, Indignados, Pingüinos, and Arab Spring activists.

Labor leaders, scholar-activists, pro-independence leaders, feminists, the Christian Left, environmentalists, lawyers, and other sectors seized the opportunity, forming a coalition of thirty-five organizations called Todo Puerto Rico por Puerto Rico. They aimed to ride the momentum built by University of Puerto Rico (UPR) students while preparing for the widely anticipated neoliberal attack on public higher education. ${ }^{8}$ Veteran organizers saw the student movement as a model to imitate as they expanded, sustained, and escalated the Todo Puerto Rico por Puerto Rico Coalition. Calls for a general strike reverberated within Coalition meetings, union halls, and intellectual circles throughout the island. The coalition demanded an end to the privatization of public goods, an end to the weakening of institutions that provide essential public services, and the preservation of cultural institutions.

\footnotetext{
7 Republican Puerto Rico Governor Luis Fortuño appointed an economic advisory council (CAREF) that, unsurprisingly, prescribed a cocktail of neoliberal policies within 6 days of the governor's inauguration in January of 2009. Their policy prescriptions are detailed in a report that they issued on January 8th, 2009. The report is available at: <http://reformagubernamental.uprrp.edu/CAREF-Informe\%2OFiscal.pdf>.

${ }^{8}$ See Alessandra Rosa's (2015) “Resistance Performances: (Re)constructing Spaces of Resistance and Contention in the 2010-2011 University of Puerto Rico Student Movement," José A. Laguarta Ramírez's (2016) “Struggling to Learn, Learning to Struggle: Strategy and Structure in the 2010-11 University of Puerto Rico Student Strike," and José E. García Oquendo's 2010 “Huelga Estudiantil de Abril 2010: Una Huelga en Defensa de la Educación Pública Superior" for rich accounts of the 2010-2011 UPR strikes. These are available http://digitalcommons.fiu.edu/cgi/viewcontent.cgi?article=2956\&context=etd; https://academicworks.cuny.edu/gc_etds/1359/; https://www.facebook.com/notes/garc\%C3\%ADa-enrique-jos\%C3\%A9/huelga-estudiantil-deabril-2010-una-huelga-en-defensa-de-la-educaci\%C3\%B3n-p\%C3\%BAblica-s/424789132025/.
} 
The student movement showcased democratic decision-making and deliberative practices to plan direct actions, set the terms of negotiations with university administrators and government officials, and ratify the agreements made at the table. They also devoted significant efforts to recruiting new organizers for youth groups, including the Unión de Juventudes Socialistas, J-23, Juventud Hostosiana, Juventud del Partido Independentista Puertorriqueño, Organización Socialista Internacional, Federación Universitaria Pro Independencia, and MASFALDA. These practices of democratic and inclusive debate - coupled with a strong organizational structure allowed the students to occupy the UPR's main campus for sixty-two days.

Thanks to this wave of activism, the Puerto Rican Left scored important victories during the Fortuño administration (2009-2013). Not only did students stop a system-wide tuition hike and save tuition waivers for athletes, student workers, and honor students (Tormos N.d.), but environmentalists also blocked the construction of a natural gas pipeline and the development of the North Ecological Corridor, which would have sacrificed the area's unique biodiversity in order to build luxury resorts. Civil rights lawyers united to defeat a referendum in which the Fortuño administration tried to curtail the right to bail.

These victories were hard fought victories and left the groups that fought them experiencing exhaustion (Coalición Todo Puerto Rico por Puerto Rico). ${ }^{9}$ These groups challenged policymakers that were reluctant to engage in negotiations and eager to flex their repressive capacities. During this period, the only politician from governor Fortuño's New Progressive Party that met with students during the 20102011 wave of contention was the District 8 representative Antonio "Toñito" Silva, who presided the Budget Committee in the Puerto Rico House of Representatives. Despite having identified funds that could be mobilized to avoid tuition fee increases, the Fortuño administration continued to push for policies that reduced the budget for higher education and placed the burden of addressing the fiscal crisis on students. The Speaker of the House and the President of the Senate both rejected meeting with

\footnotetext{
9 An internal movement analysis document of the Coalition recounted the Left's victories in 2009-2010 while recognizing the exhaustion that most coalition partners experienced.
} 
students and decided to close off both chambers to the public so as to avoid protests inside the Capitol building. This decision drew widespread criticism from various sectors of the Puerto Rican civil society and produced one of the most violently repressive days in recent Puerto Rican history. The Puerto Rico police force used riot police to assault students and supporters, carried out illegal arrests, and lost multiple lawsuits for their aggression against activists. Students, parents, elders, women of color, and labor union leaders were shown bloodied in national and international media outlets after violent confrontations with riot police while marching at the premises of the Capitol building and while trying to deliver food and supplies to activists occupying the university. These instances of repression were part of a pattern of sustained repressive practices (Bonilla and Boglio 2010; Brusi 2011; Lebrón 2015; Lebrón 2017). The Federal Department of Justice Civil Rights Division began an investigation of the Puerto Rico Police, which found a pattern of rights violations and mandated a series of changes to the police force. ${ }^{10}$

These sectors eventually came together at a massive People's Assembly, where they organized an island-wide work stoppage and mobilized tens of thousands at marches. The movement began to resemble the campaigns that eventually drove the US military out of Vieques Island in 2003. It seemed like the stage was set for a broader emancipatory struggle, one that could transition from resistance to revolution. Unfortunately, the forces committed to continuing the colonial and neoliberal order in Puerto Rico proved to be stronger than those that fought to subvert it.

The Todo Puerto Rico for Puerto Rico Coalition only managed to coordinate actions with more radical groups like the Frente Amplio de Solidaridad y Lucha around the student struggle. Unions belonging to the Coalición Sindical, which participated in the Todo Puerto Rico for Puerto Rico Coalition, were at odds with more radical unions belonging to the Coordinadora Sindical and the umbrella group Frente Amplio de Solidaridad y Lucha. Coalición Sindical unions rejected the calls for a general strike that dominated the Left, including the Todo Puerto Rico por Puerto

10 The US Department of Justice Report on its Investigation of Puerto Rico Police Department is available at: https://www.justice.gov/sites/default/files/crt/legacy/2011/o9/o8/prpd_letter.pdf 
Rico Coalition. Public sector unions feared losing their certification as sole representatives of their union members in their workplaces, given that PR Law 45 of 1998 allowed central government employees to unionize but prohibited strikes (Bonilla and Boglio 2010). The Todo Puerto Rico por Puerto Rico Coalition's insistence on a general strike that did not have the support of a majority of union members nor massive public support, their inability to broker alliances between quarreling sectors of the labor movement, and their failure to appeal to a broader base of Leftist groups led to the eventual demise of the Coalition.

\section{Assessing the Balance of Forces}

The Puerto Rican Left has resisted a number of neoliberal attacks in the past, but the fiscal and humanitarian crisis exacerbated by Hurricane María is testing this ability. In the wake of the storm, both veteran and new activists have had to migrate or accept jobs with entities complicit in neoliberal policy making. But left-wing activism is still taking place and, in some instances, deepening its practices.

Hurricane María brought a renewed awareness of what it would take for the Left to remain relevant and impactful in Puerto Rican politics and society. In the wake of Hurricane María, socialist, environmentalist, and youth activist groups set up a network of mutual assistance centers (Centros de Apoyo Mutuo). ${ }^{11}$ Beyond the urgency of first aid, food, water, and other basic supplies, solidarity brigades that ventured into the island's devastated mountainous regions quickly learned that the needs of these communities far exceeded what the government planned to deliver. In the community of Bucarabones in the municipality of Las Marías, solidarity brigades were the first groups to reach the community, two weeks after the passage of the hurricane. ${ }^{12}$ They discovered that, after decades of government neglect, most residents in Bucarabones expected getting cut off from the rest of the island in the aftermath of Hurricane María. They found community residents sourcing water from

\footnotetext{
"Some of these groups, like the Centro de Apoyo Mutuo de Caguas, existed prior to the storm and were important brokers of relationships among the emerging groups.

${ }^{12}$ Interview with organizer of a Centro de Apoyo Mutuo on 1/4/18.
} 
wells and consuming the food that they had stored to last for weeks. Solidarity brigade organizers quickly recognized that the community's needs entailed more than just basic goods. The relevance and survival of the Puerto Rican Left in the midst of this disaster, they realized, would depend on their ability to listen to and learn from these communities and address deep-rooted inequalities. While autonomous recovery efforts emerged, local and federal government officials divided their time between media appearances and scrambling to manage the disaster relief effort. Activists in the island highlighted the irony of having a governor who ran for his position as an erudite technocrat with a sophisticated plan for everything but failed to prepare for a natural disaster and follow emergency protocols already in place.

Since the storm, the farmers' and food sovereignty movements have drawn support from Vía Campesina and the climate justice movement to provide rapid response to frontline communities affected by the disaster. Mutual aid groups from the Puerto Rican diaspora and the Climate Justice Alliance joined local activists to get supplies to local farmers, rebuild ecosystems, and coordinate relief efforts with local and US labor unions. These groups resisted the nonprofit, corporate, and government-led network, Unidos for Puerto Rico, which raised millions of dollars in donations since the disaster. These groups raised questions about the allocation of the funds collected in the name of relief and argued that they had yet to reach the Puerto Rican population. They denounced government efforts to implement false solutions, such as privatizing public utilities and education, and raised public awareness about the Federally imposed Fiscal Control Board's plans to mandate fiscal austerity policies that would further strangle the already precarious living conditions of working class Puerto Ricans. Moreover, they politicized the recovery process, which produced widespread frustration, manifesting as roadblocks, picket lines, and occupations of government buildings.

On the other hand, right-wing groups have developed strong relationships with the Republican-led government in Washington and have become a powerful force within the island's major political parties: the New Progressive Party (NPP) and the Popular Democratic Party (PDP). The NPP's base includes religious fundamentalists, and its ample campaign funding comes from local capitalists. Sheltered by the darkness that 
swept the island after the hurricane, the NPP exploited the crisis to side step legislative hearings, silence the opposition, introduce a religious freedom bill, grant no-bid contracts to dubious providers, and push conservative criminal justice reforms.

In January of 2018, Governor Ricardo Rosselló confirmed his intentions to continue the legacy of his father, former governor Pedro Rosselló, by selling the island's besieged power authority. A week later, he announced the privatization of the primary and secondary public school system. In April, he announced a sweeping labor reform and the closure and consolidation of a number of government agencies.

His father had tried to win public support for similar schemes by claiming that the revenue gained from privatizing public goods would fund social spending, including public employee pensions and universal health care. Instead, his administration took on expensive mega-projects, which handed lucrative contracts over to campaign donors but failed to raise the money necessary to sustain welfare programs. The government's efforts to privatize Puerto Rico's Public Power Authority (PREPA) and public education are an indicator's of the Right's current strength. The NPP has long wanted to enact these policies, but previous administrations deemed public sector unions - and the Left more generally — too strong to undertake such an attack.

The crisis that followed Hurricane María opened the door for the Rosselló administration to consolidate their plans for implementing neoliberal policies. ${ }^{13}$ The members of some of the island's strongest unions were caught fatigued. Power line workers, for example, experienced exhaustion, toiling around the clock to restore power while facing attacks from citizens who blame them for the government's inability to restore power. Meanwhile, many teachers worked in schools without electricity while facing the threat of school closures. Government workers had to fight

\footnotetext{
${ }^{13}$ Naomi Klein's involvement in analyses of disasters and, specifically the policies that followed Hurricane María, have sparked an intense and divisive debate within the Puerto Rican intellectual and activist community. Some have recognized the value of Klein's (2018) attention to the neoliberal policymaking in the wake of disasters in the context of Puerto Rico while others argue that these observations are not new. Rather, Puerto Rican intellectuals have produced important analyses that tend to be ignored both locally and internationally.
} 
neoliberal labor policy reforms on multiple fronts: against the Fiscal Control Board and against the local government of Ricardo Rosselló.

The privatization announcement was carefully timed. Vulture funds had been looking over the governor's shoulder, pressuring him to include the privatization of PREPA's assets, including energy generation plants, in their fiscal recovery proposal. Selling off public assets was always part of his vision — even if he never revealed it on the campaign trail. A week after the announcement, UTIER, the PREPA workers' union, issued a call for solidarity across all sectors of the Puerto Rican Left to renew their resistance to privatization. Many answered this call.

Resisting privatization efforts in Puerto Rico will require tactical diversity and innovation, transversal cooperation across different sectors of the Left, and embracing the energy of emerging groups aiming to build popular mobilizations, such as the Colectiva Feminista en Construcción and the network of mutual assistance centers. Younger generations of Leftist organizers have shed some of the old Left's baggage, but continue to grapple with the sediments of longstanding tactical divides. Recent examples of these divides were observed in the internal divisions of the Todo Puerto Rico por Puerto Rico Coalition in relation to deploying the tactic of a general strike, and more recently, with the divisions between more radical blocs (e.g. Jornada Se Acabaron las Promesas) and labor unions during the May $1^{\text {st }}$ demonstrations in 2017 and 2018. While disagreements about tactics persist, younger generations of activists have not had to take sides on the extremely divisive issue of armed struggle, as those groups have mostly disbanded. Now debate centers on electoral participation, collaboration with the PDP, on mutual assistance projects, and on diversification.

\section{The Puerto Rican Electoral Question}

Pedro Albizu Campos once referred to ballot boxes as coffins designed for the burial of the Puerto Rican nation. Under his leadership, the nationalist party militarized, rejecting the electoral process. The Puerto Rico Independence Party (PIP) stepped in to provide an electoral alternative for left-wing voters. Though these two sectors have come together to resist militarism, right-wing influences on public education, the 
displacement of marginalized communities, repression, and environmentally hazardous projects, the disagreement over electoral participation has persisted.

In 2016, the Obama administration worked in collaboration with a GOP-led Congress to create an unelected Fiscal Control Board with the power to impose fiscal policies in order to ensure the payment of Puerto Rico's ballooning debt. That year's elections revealed a growing discontent with the island's three main parties and with the electoral process more generally. Between 2012 and 2016, Puerto Rico experienced a remarkable 22 percent drop in electoral turnout (from 77 to 55 percent). While these numbers are still higher than turnout in the United States, Puerto Rico has historically experienced voter turnout nearing 80 percent.

The Left has yet to find ways of harnessing voters' obvious frustration. Leftists who reject the electoral process argue that participating in elections legitimizes the colonial order, while others argue that boycotting will limit the Left's ability to curtail government corruption and hold elected officials accountable. This group is further divided between those who support the PDP in order to defeat right-wing candidates and those that who support the more left-wing parties, the PIP and the Working People's Party (PPT). The first tactic handed the PDP slim victories against two recent NPP reelection bids: both Rosselló and Fortuño lost by a margin of less than .6 percent. Without the Left's support, Puerto Rico would have had uninterrupted NPP rule since 2000.

In recent elections, neither the PIP nor the PPT has passed the 3 percent threshold necessary to remain in the ballot for future elections. The pro-independence party has failed to do so since 2004, but have been able to win at large seats in the House and Senate. The PPT, which participated in elections for the first time in 2012, has never had legislative representation. Given this landscape, the Left's ability to claim electoral victory seems significantly limited.

Various voices within the Left have suggested forming a party combining the PIP and the PPT, but party leaders have yet to agree. Some argue that the Left must address its internal differences and define the purpose of these alliances before uniting (Pabón Ortega 2014). These critics only feel compelled to join a coalition focused on 
building radical democracy, as opposed to one that prioritizes the question of status (Pabón Ortega 2014).

\section{Building Power in the Streets}

Despite these electoral failures, left-wing forces have shown their strength in the streets and in communities. Umbrella organizations like Jornada Se Acabaron las Promesas and the short-lived Concertación Puertorriqueña en Contra de la Junta joined culture workers like Papel Machete and AgitArte to mount a sustained campaign against the Fiscal Control Board. Feminists from growing organizations like the Colectiva Feminista en Construcción have built popular resistance to patriarchy, neoliberalism, and authoritarianism. They disrupted two of the island's main highways on two separate occasions, mobilized hundreds for a feminist assembly, formed a mutual assistance center, and forced the resignation and prosecution of Guaynabo mayor Hector O’Neill for sexual assault against a municipal employee.

An amalgam of Leftist organizations led work stoppages while thousands flooded Puerto Rico's financial district in Hato Rey during the May Day demonstrations in 2017 and 2018. The farmer's movement has grown dramatically in the past decade, with a growing number of independent and sustainable farming projects underway. Activist leaders have joined the Climate Justice movement at the United Nations climate change negotiations and have strengthened their ties with the anti-capitalist farmer's movement Vía Campesina. The environmental justice movement has successfully mobilized against pipeline projects and used the media attention following Hurricane María to call for a just energy transition.

The network of mutual assistance centers throughout the island has breathed new life into the Left. They are working to meet the needs of isolated communities that the state, local, federal governments have ignored, moving the people from resilience to resistance. While some have warned that the Left should also pressure the state to meet its responsibilities to the population (Pérez Soler 2017), mutual assistance center organizers have criticized the false dichotomy of bottom-up and top-down 
approaches to organizing (Roberto 2017). The vitality of the Puerto Rican Left must come from a synthesis of these approaches.

\section{Towards an Emancipatory Diversity}

Puerto Rican feminists argue that the Left's vitality will also depend on its ability to build more inclusive leadership groups. While left-wing groups have long fought to diversify government, schools, and other societal institutions, some have resisted internal diversification. Historically, the Puerto Rican Left has been at its strongest when it has identity, ideological, and tactical diversity. The upsurge that it experienced in the 1960s came when leaders focused on organizing marginalized groups and workers, fostering unity in diversity, strengthening youth and student groups, opening dialogue across different sectors of the Left, and developing international relationships of solidarity. ${ }^{14}$ These approaches encouraged collaboration despite disagreements about tactics, electoral participation, and organizing priorities. It also allowed the Left to deploy new tactical repertoires, mounting massive campaigns, organizing strikes, and supporting cultural work.

Some have dismissed these calls to diversify, expressing a desire to avoid what they consider a postmodern or neoliberal concern for identity politics. ${ }^{15}$ But others see diversity as a form of strength (Page 2008; Tormos 2017a; Young 1990; Weldon 2006). Adopting this second approach entails building opportunities for dialogue despite differences, amplifying marginalized group's voices and perspectives, and prioritizing the issues of oppressed groups while fighting against shared grievances. Most importantly, it involves building leadership from the bottom up and trusting those without prestigious educations who possess the knowledge that comes from the pedagogy of the oppressed.

New groups have taken important steps in this direction. Members of the Juventud Hostosiana, which took a prominent role in the most recent student strike, have

\footnotetext{
${ }^{14}$ Ángel Pérez Soler (2014) and José Ché Paralitici (2017) chronicle this history.

${ }^{15}$ See for example Pabón Ortega (2014).
} 
embraced diversity and declared themselves intersectional feminists, anti-colonialists, and ecologists (Juventud Hostosiana 2017). The leaders of the feminist organization Colectiva Feminista en Construcción also played active roles in the student movement. The Colectiva, now a powerful force within the Puerto Rican Left and in Puerto Rican politics more generally, has adopted an intersectional feminist organizing praxis and pushed the Left to fulfill its commitment to ending oppression by aiming to defeat capitalism and patriarchy simultaneously. ${ }^{16}$

\section{The Path Forward}

Moving forward, the American and international Left will debate whether to use Puerto Ricans as a pawn in their battles against the Trump administration or to afford them a substantive role in these efforts. Affording Puerto Ricans a substantive role in achieving Leftist victories would entail refraining from framing the urgency of supporting Puerto Ricans in terms of their US citizenship, and grounding solidarity in relation to values of radical democracy and emancipation. It entails adopting an intersectional solidarity approach to organizing that recognizes the multiple dimensions of oppression of Puerto Ricans, represents their claims and leaders, and allocates resources to address their issues (Tormos 2017b). This orientation runs counter to how mainstream American politicians have treated Puerto Ricans. Democrats have launched voter registration campaigns in hopes of using recent migrants as cannon fodder for the war against the Republicans - a cause that few Puerto Ricans seem eager to join. ${ }^{17}$ Liberals hope to enlist the Puerto Rican diaspora in the 2018 midterm elections, forgetting that Puerto Ricans, and Latinxs more generally, have often failed to reap the promised benefits of Democratic electoral victories.

\footnotetext{
16 https://www.scribd.com/document/263057948/La-Manifiesta-Colectiva-Feminista-enConstruccion

${ }^{17}$ For an early report on these voter registration efforts in Florida and the Puerto Rican response see: http://www.orlandosentinel.com/news/politics/political-pulse/os-puerto-rican-voterregistration-20180126-story.html
} 
In the days that followed Hurricane María, Puerto Ricans took matters into their own hands. Groups of retired line workers and electricians restored power in isolated sectors. Communities came together to rebuild their own bridges, literally and metaphorically. Collectively, they dispelled the myths that portray them as lazy and dependent on the government. Hurricane María did not only bring devastation to the island. It also opened opportunities for both the Left and the Right. In the coming years, the Left can increase its organizing capacity by embracing the energy that stems from the alliances of unions, environmentalists, farmers, students, and scholaractivists that have formed on the ground, in the Puerto Rican diaspora, and internationally. The Left's adoption of an inclusive and popular resistance organizing approach will help determine its ability to defeat the neoliberal attacks on its public services and institutions.

\section{References}

Bakker, Ryan, Erica Edwards, Seth Jolly, Jonathan Polk, Jan Rovny, and Marco Steenbergen. 2014. "Anchoring the experts: Using vignettes to compare party ideology across countries." Research and Politics (October-December): 1-8.

Barker, Colin. 1995. "'The Muck of Ages': Reflections on Proletarian Self-emancipation.” Studies in Marxism (2): 81-112.

Bonilla, Yarimar and Rafael Boglio. 2010. "Puerto Rico in Crisis: Government Workers Battle Neoliberal Reform.” NACLA. Published online on January 5, 2010. Available at: https://nacla.org/article/puerto-rico-crisis-government-workers-battle-neoliberalreform.

Brusi, Rima. 2011. “A new, violent order at the University of Puerto Rico." Graduate Journal of Social Science 8 (1): 42-60.

Cochrane, Christopher. 2015. Left and Right : The Small World of Political Ideas. Ed. Christopher Cochrane. Montreal: McGill-Queen's University Press.

Colectiva Feminista en Construcción. 2017. "La Manifiesta." Available at: https://www.scribd.com/document/263057948/La-Manifiesta-Colectiva-Feministaen-Construccion 
García Oquendo, José E. 2010. "Huelga Estudiantil de Abril 2010: Una Huelga en Defensa de la Educación Pública Superior." Available at: https://www.facebook.com/notes/garc\%C3\%ADa-enrique-jos\%C3\%A9/huelgaestudiantil-de-abril-2010-una-huelga-en-defensa-de-la-educaci\%C3\%B3np\%C3\%BAblica-s/424789132025/.

Juventud Hostosiana. 2017. "Principios de la Juventud Hostosiana."

Klein, Naomi. 2018. The Battle for Paradise: Puerto Rico Takes on Disaster Capitalists. Chicago: Haymarket Books.

Laguarta Ramírez, José A. 2016. "Struggling to Learn, Learning to Struggle: Strategy and Structure in the 2010-11 University of Puerto Rico Student Strike." Ph.D. diss. City University of New York.

LeBrón, Marisol. 2015. "Policing Solidarity: State Violence, Blackness, and the University of Puerto Rico Strikes.” Souls 17 (1-2 January-June): 113-134.

LeBrón, Marisol. 2017. "Carpeteo Redux: Surveillance and Subversion against the Puerto Rican Student Movement.” Radical History Review 128 (May): 147-172.

Movimiento Socialista de Trabajadores. 1999. “¿Qué es y porque lucha el MST?” Available at: http://www.bandera.org/que-es-y-porque-lucha-el-mst/

Pabón Ortega, Carlos. 2014. Polémicas: Política, Intelectuales, Violencia. San Juan: Ediciones Callejón.

Page, Scott E. 2008. The Difference: How the Power of Diversity Creates Better Groups, Firms, Schools, and Societies. New Jersey: Princeton University Press.

Paralitici, José Ché. 2017. Historia de la Lucha por la Independencia de Puerto Rico. San Juan: Publicaciones Gaviota.

Pérez Soler, Ángel. 2014. La Nueva Lucha de Independencia: La Contribución a la Lucha de la Independencia del Movimiento Pro Independencia y su Transición al Partido Socialista Puertorriqueño, 1959-1971. Ph.D. diss. Centro de Estudios Avanzados de Puerto Rico y el Caribe.

Pérez Soler, Ángel. 2017. "Abuso con la autogestión.” El Nuevo Día. Published online on November 16 , 2017. Available at: 
https://www.elnuevodia.com/opinion/columnas/abusoconlaautogestion-columna$2374764 /$.

Rosa, Alessandra. 2015. "Resistance Performances: (Re)constructing Spaces of Resistance and Contention in the 2010-2011 University of Puerto Rico Student Movement." Ph.D. diss. Florida International University.

Roberto, Giovanni. 2017. "Perdón, permiso." Centro para el Desarrollo Político, Educativo, y Cultural Blog. Published online on November 26, 2017. Available at: https://www.cdpecpr.org/single-post/2017/11/26/ Perd\%C3\%B3n-permiso.

Tormos, Fernando. 2017a. "Mobilizing Difference: The Power of Inclusion in Transnational Social Movements." Ph.D. diss. Purdue University.

Tormos, Fernando. 2017b. "Intersectional Solidarity." Politics, Groups, and Identities (5) 4: 707-720.

Tormos, Fernando. Nd. "Enacting Intersectional Solidarity in the Puerto Rican Student Movement." Forthcoming in Gendered Mobilizations. Edited by Celeste Montoya, Jill Irvine, and Sabine Lang.

Weldon, S. Laurel. 2006. "Inclusion, Solidarity, and Social Movements: The Global Movement against Gender Violence." Perspectives on Politics 4 (1): 55-74.

Young, Iris Marion. 1990. Justice and the Politics of Difference. New Jersey: Princeton University Press. 